\title{
Comparative effect of feeding various concentrations of sugar beet pulp to estimate the increase in live body weight and their economic values in Damani
} goats

\author{
Arsalan Khan ${ }^{1 *}$, Israr ud Din ${ }^{1}$, Akhtar Ali ${ }^{1}$, Amjad Ali ${ }^{1}$, Muhammad \\ Jamil $^{2}$, Safiullah ${ }^{1}$ and Muhammad Fahim Ullah ${ }^{3}$ \\ 1. Livestock Research \& Development Station, Paharpur, Dera Ismail Khan-29050-Pakistan \\ 2. Arid Zone Agriculture Research Center, Pakistan Agriculture Research Council, Dera Ismail Khan-29050- \\ Pakistan \\ 3. Faculty of Veterinary and Animal Sciences, Gomal University, Dera Ismail Khan-29050-Pakistan \\ *Corresponding author's email: drarsalankhandvm@gmail.com \\ Citation \\ Arsalan Khan, Israr ud Din, Akhtar Ali, Amjad Ali, Muhammad Jamil, Safiullah and Muhammad FahimUllah. \\ Comparative effect of feeding various concentrations of sugar beet pulp to estimate the increase in live body weight \\ and their economic values in Damani goats. Pure and Applied Biology. Vol. 9, Issue 1, pp635-639. \\ http://dx.doi.org/10.19045/bspab.2020.90069
}

Received: 04/09/2019

Revised: 01/12/2019

Accepted: 00/12/2019

Online First: 20/12/2019

\section{Abstract}

The present study was designed for the determination of the comparative effect of feeding various concentrations of sugar beet pulp (SBP) and to estimate the increase in live body weight and their economic values, inDamani goats maintained at Livestock Research and Development Station, Paharpur, Dera Ismail Khan. The feeding trial was conducted on 20 numbers of Damani kids of06 months age and average weight of $28 \pm 0.5 \mathrm{Kg}$. The animals were randomly distributed into four different groups,vizGroup A, B, C and Group D, comprising 05 animals each. The animals of each group were fed with untreated sugar beet pulp, $2 \%$ urea treated SBP, $4 \%$ urea treated SBP and control group, respectively. The trial was conducted for the period of 35 days post adaptation period of 10 days. Average feed intake of various groups, A, B, C and D was $1005.4 \pm 3.034,1116 \pm 3.069,1048.5 \pm 3.085$ and $1034.2 \pm 3.024$, per day respectively. Average weight gain of the animals of different groups was $123.736 \pm 0.543,138.99 \pm 3.22,145.865 \pm 3.022$ and $113.977 \pm 3.468$, per day respectively. As per statistical tools, it was found from the study that the animals of group $\mathrm{C}$, fed with $4 \%$ urea treated $\mathrm{SBP}$ showed significantly higher weight gain $(\mathrm{P}<0.05)$ compared to other groups (Group A, B and D). The feed conversion ratio of all the groups was also estimated, and found $9.084 \pm 0.0446,8.66 \pm 0.0378,7.37 \pm 0.0408$ and $9.825 \pm 0.029$, per day respectively, regarding which the group A showed higher feed conversion ratio. Therefore, in this study, it has been concluded that the animals of Group C, fed with $4 \%$ urea treated SBP showed maximum weight gain. It reveals that the animals raised by the farmers for fattening purposes would show improved weight gain if their feeding ration is supplemented with sugar beet pulp treated with urea @ 4\%.

Keywords: Damani Goat; Feed Conversion Ratio; Sugar Beet Pulp; Urea. 


\section{Introduction}

Livestock population has a vital role in the economy of Pakistan and goat is one of the important livestock species. Goat commonly referred as poor man's cow, is multipurpose animal, reared for meat, milk, hide, fiber and manure purpose. Damani goat belongs to District Dera Ismail Khan, Bannu and Kohat (Khyber Pakhtunkhwa province of Pakistan). It is small sized breed of goats, with convex facial features, screw or spiral shaped horns. Horn color is black with little brown percentage, straight ears and straight medium sized hair on the body. The average body weight is $29-35 \mathrm{Kg}$, patchy colored body coat of black and tan color[1].

Beta vulgaris, sugar beet plant, grown commercially for the production of sugar, is rich in sucrose concentration, contained in its roots. Roots of the sugar beet comprises $75 \%$ water level, 20\% sugar level and 5\% pulp, as by-product after sugar processing. This pulp is insoluble in water and largely comprises of cellulose, hemicellulose, pectin, lignin and widely used in the animal feed. But sugar beet pulp lacks vitamins, therefore, extra forage consumption is necessary to fulfill the nutritional requirements of the animals [2].Sugar beet exclusively grows in temperate zone. Its foliage is rich, brilliant green colored and attains a height of $35 \mathrm{~cm}$ or 14 inches. Numerous broad leaves grow in the form of tuft from the crown of the beet, usually leveled with ground or slightly above the ground level. Sugar beet pulp comprises $9.1 \%$ crude proteins, $0.5 \%$ ether extract, $6 \%$ sucrose and 3-4\% soluble ash [3].

Sugar beet pulp is palatable, highly digested fiber source of ration, used in the animal feed. It gives cooling effect in the animals and gives their skin bloom and healthy appearance. It is succulent, gives firmness to feces and boost feed intake, ultimately weight gain and high energy yield in ruminal fermentation. It can be used as energy supplement and finishing ration in beef animals, as a rich source of digestibility [4, 5]. It contains high content of glucans and pectin (soluble fibers), which are fermented to acetates in ruminants. It is low cost byproduct of sugar industries, sold in the form of meal and pellet and can be included as high-quality animal as well as poultry feed [6].

The main objectives of the study were to investigate and analyze the feeding of various concentrations of untreated and urea treated sugar beet pulp in Damani Goats and to determine the weight gain of animals fed with sugar beet pulp.

\section{Materials and methods}

The experimental trial was conducted on Damani Goats maintained at Livestock Development and Research Station, Paharpur, District Dera Ismail Khan and the chemical analysis of experimental feed was performed at the Department of Animal Nutrition, The University of Agriculture, Peshawar.

The ration was iso-caloric and isonitrogenous according to National Research Council (NRC) recommendations, 2007. The required quantity of sugar beet pulp (SBP) was collected commercially from Al-Moiz Sugar Mill, District Dera Ismail Khan. Sugar beet pulp was treated with $2-4 \%$ urea solution. The solution was sprinkled on SBP, followed by air tight covering of the sugar beet pulp to accomplish anaerobic conditionsfor one week time. Thereafter, the ration was opened for two hours to eliminate ammonia gas for prevention of ammonia toxicity and the experimental ration was ready for feeding of the animals (Damani Goats).

The animals were randomly distributed in four different groups, viz Group A, B, C and Group D, comprising 05 animals each, fed with untreated sugar beet pulp (SBP), 2\% urea treated SBP, $4 \%$ urea treated SBP and control group, respectively (Table 1). The ration was offered as a supplement with basal 
ration as stall feeding, for a period of 10 days for adaptation, followed by 35 days of experimental phase. The basal diet comprised chopped berseem, having 30\% dry matter. The proximate analysis of the SBP samples including analysis of dry matter, ether extract, crude fiber and crude protein, was done at the Department of Animal Nutrition, The University of Agriculture, Peshawar. The total feed intake per day of each group, weekly weight gain of the animals using weight scale, feed conversion ratio and cost of feed consumed was determined in this study.

Table 1. Experimental layout

\begin{tabular}{|c|c|c|}
\hline Ration & Group & Damani Kid Tag No. \\
\hline Untreated Sugar Beat pulp & A & A1, A2, A3, A4, A5 \\
\hline $2 \%$ Urea treated sugar beet pulp & B & B1, B2, B3, B4, B5 \\
\hline $4 \%$ Urea treated sugar beet pulp & C & C1, C2, C3, C4, C5 \\
\hline Control Group & D & D1, D2, D3, D4, D5 \\
\hline
\end{tabular}

\section{Results and discussion}

The animals of Group A, B, C and Group D were fed with untreated sugar beet pulp (SBP), 2\% urea treated SBP, 4\% urea treated SBP and control group, respectively and weekly average feed intake was calculated for first 05 weeks. The results revealed that the animals of group B, fed with $2 \%$ urea treated SBP showed significantly higher feed intake $(\mathrm{P}<0.05)$, throughout the trial, from the $1^{\text {st }}$ week to $5^{\text {th }}$ week, compared to the animals of rest of the groups (Table 2). Weekly average weight gain (in grams) at different dietary feed from week 1 to $5^{\text {th }}$, was also determined and the results revealed that the average weekly weight gain of the animals of Group C, fed with 4\% urea treated SBP, was significantly higher $(\mathrm{P}<0.05)$ than the other groups except animals of Group B, fed with $2 \%$ urea treated SBP in the $2^{\text {nd }}$ week showed higher average weight gain of $141 \pm 3.02$ grams than Group C with $132.45 \pm 2.67$ (Table 3). Our results are in agreement with the study in which it was reported that inclusion of sugar beet pulp at the rate of $5 \%$ and $10 \%$, in the diet of Gimizah Chicken resulted in the increased feed intake of hens. Whereas, the weight gain of the hens, was significantly $(\mathrm{P} \leq 0.001)$ increased since $9^{\text {th }}$ to $19^{\text {th }}$ week of feeding the experimental ration[6]. In other study 3\% urea treated sugar beet pulp was highly recommended in the ewes feeding for improvement of feed intake as well as boosting the body weight in growing stage [7]. Similar studies were conducted in which the dried sugar beet pulp was used as $50 \%$ replacement ration in Angora Goat kids, which are also in agreement with our research [8]. It was revealed from a research study on fattening of animals that the SBP, produced as byproduct from the sugar processing industries represented a highly valuable energy rich diet, of superior nutritious quality can be utilized as supplement ration in the feed of productive cows and for intensive farming of the rams and bulls [9].

The FCR of all groups was calculated in terms of feed intake and weight gain on weekly basis, as mentioned in (Table4). The results revealed significantly higher FCR value $(\mathrm{P}<0.05)$ for Group B, fed with $2 \%$ urea treated SBP than the other groups fed with various concentration of urea treated SBP as well as control group fed on routine ration lacking SBP supplementation. Our results coincide with the results of different studies conducted in the determination of FCR values affected with the supplementation of SBP. In this regard it was 
revealed that the feed conversion ration of the chickens was significantly improved by the supplementation of SBP in their routine feeding $[10,11]$.

Table2. Weekly average feed intake (gram) at different dietary feed from week 1 to $5^{\text {th }}$

\begin{tabular}{|c|c|c|c|c|c|c|}
\hline \multirow{3}{*}{$\begin{array}{c}\text { Groups } \\
\text { A (Untreated } \\
\text { SBP) }\end{array}$} & Wk. $1^{s t}$ & Wk. $2^{\text {nd }}$ & Wk. $3^{r d}$ & Wk. $4^{\text {th }}$ & Wk. $5^{\text {th }}$ & \multirow{2}{*}{ Average } \\
\hline & \multicolumn{5}{|c|}{ Mean \pm S. E } & \\
\hline & $920 \pm 3.23$ & $1027 \pm 3.16$ & $950 \pm 3.9$ & $1070 \pm 2.76$ & $1060 \pm 2.12$ & $1005.4 \pm 3.034$ \\
\hline $\begin{array}{l}\text { B }(2 \% \text { urea } \\
\text { treated SBP })\end{array}$ & $977 \pm 2.83$ & $1060 \pm 2.977$ & $1028 \pm 2.81$ & $1176 \pm 3.97$ & $1200 \pm 2.76$ & $1116 \pm 3.069$ \\
\hline $\begin{array}{l}\mathrm{C}(4 \% \text { urea } \\
\text { treated SBP })\end{array}$ & $940 \pm 2.10$ & $986 \pm 3.776$ & $1022 \pm 2.81$ & $1060 \pm 3.98$ & $1126 \pm 2.76$ & $1048.5 \pm 3.085$ \\
\hline D (Control) & $935 \pm 3.67$ & $977 \pm 3.26$ & $1014 \pm 2.98$ & $1020 \pm 3.0$ & $1100 \pm 2.21$ & $1034.2 \pm 3.024$ \\
\hline
\end{tabular}

Table 3. Weekly average weight gain (grams) at different dietary feed from week 1 to $5^{\text {th }}$

\begin{tabular}{|c|c|c|c|c|c|c|}
\hline \multirow[b]{2}{*}{ Groups } & Wk. $1^{\text {st }}$ & Wk. $2^{\text {nd }}$ & Wk. $3^{\text {rd }}$ & Wk. $4^{\text {th }}$ & Wk. $5^{\text {th }}$ & Average \\
\hline & \multicolumn{6}{|c|}{ Mean \pm S.E } \\
\hline $\begin{array}{c}\text { A } \\
\text { (Untreated } \\
\text { SBP) }\end{array}$ & $120.2 \pm 5.77$ & $139.9 \pm 3.12$ & $121.2 \pm 5.42$ & $\begin{array}{r}109.28 \\
\pm 3.33 \\
\end{array}$ & $128.1 \pm 3.23$ & $\begin{array}{r}123.736 \\
\pm 0.543 \\
\end{array}$ \\
\hline $\begin{array}{c}\text { B }(2 \% \text { urea } \\
\text { treated } \\
\text { SBP })\end{array}$ & $130.23 \pm 3.12$ & $141 \pm 3.02$ & $132.5 \pm 3.91$ & $\begin{array}{r}138.36 \\
\pm 2.92\end{array}$ & $142.1 \pm 3.13$ & $138.99 \pm 3.22$ \\
\hline $\begin{array}{c}\mathrm{C}(4 \% \text { urea } \\
\text { treated } \\
\text { SBP })\end{array}$ & $141.93 \pm 2.65$ & $132.45 \pm 2.67$ & $149.19 \pm 3.87$ & $\begin{array}{r}143.22 \\
\pm 3.19\end{array}$ & $158.6 \pm 2.73$ & $\begin{array}{r}145.865 \\
\pm 3.022\end{array}$ \\
\hline D (Control) & $117.55 \pm 3.29$ & $127.98 \pm 3.88$ & $102 \pm 2.93$ & $\begin{array}{l}106.17 \\
\pm 3.60\end{array}$ & $119.7 \pm 3.64$ & $113.977 \pm 3.468$ \\
\hline
\end{tabular}

Table 4. Average Feed conversion ratio FCR at different dietary feed from week 1 to 5

\begin{tabular}{|c|c|c|c|c|c|c|}
\hline \multirow{2}{*}{ Groups } & Wk. $1^{\text {st }}$ & Wk. $2^{\text {nd }}$ & Wk. $3^{\text {rd }}$ & Wk. $4^{\text {th }}$ & Wk. $5^{\text {th }}$ & Average \\
\hline & \multicolumn{6}{|c|}{ Mean \pm S. E } \\
\hline $\begin{array}{c}\text { A } \\
\text { (Untreated } \\
\text { SBP) }\end{array}$ & $9.1 \pm 0.059$ & $9.2 \pm 0.067$ & $8.94 \pm 0.032$ & $8.98 \pm 0.020$ & $9.20 \pm 0.045$ & $9.084 \pm \frac{ \pm 0}{6} 0.044$ \\
\hline $\begin{array}{l}\text { B }(2 \% \text { urea } \\
\text { treated SBP })\end{array}$ & $8.99 \pm 0.023$ & $9.1 \pm 0.076$ & $8.23 \pm 0.034$ & $8.64 \pm 0.037$ & $8.67 \pm 0.019$ & $8.66 \pm 0.0378$ \\
\hline $\begin{array}{c}\mathrm{C}(4 \% \text { urea } \\
\text { treated SBP })\end{array}$ & $8.21 \pm 0.047$ & $7.15 \pm 0.0390$ & $7.36 \pm 0.0189$ & $7.87 \pm 0.0501$ & $7.1 \pm 0.049$ & $7.37 \pm 0.0408$ \\
\hline D (Control) & $9.57 \pm 0.019$ & $10.25 \pm 0.016$ & $9.94 \pm 0.027$ & $9.39 \pm 0.049$ & $9.87 \pm 0.0341$ & $9.825 \pm 0.029$ \\
\hline
\end{tabular}




\section{Conclusion}

It has been concluded from this study that the animals fed with urea treated sugar beet pulp at the rate of $2-4 \%$, showed maximum FCR and improved weight gain. Moreover, the sugar beet pulp is very economical and low cost by-product of sugar industries, sold in the form of meal and pellet and can be included as high-quality and low cost animal feed, particularly by the farmers who raise the animals for fattening purpose.

\section{Authors' contributions}

Conceived and designed the experiments: A Khan, IU Din, A Ali, A Ali, M Jamil, Sfiullah \& MF Ullah, Performed the experiments: A Khan, IU Din, A Ali, A Ali, M Jamil, Sfiullah \& MF Ullah, Analyzed the data: A Khan, IU Din, A Ali, A Ali, M Jamil, Sfiullah \& MF Ullah, Contributed materials/ analysis/ tools: A Khan, IU Din, A Ali, A Ali, M Jamil, Sfiullah \& MF Ullah, Wrote the paper: A Khan, IU Din, A Ali, A Ali, M Jamil, Sfiullah \& MF Ullah.

\section{References}

1. Nazeer M \& Shah SH (2018). Morphological characterization of indigenous goats breeds of Khyber Pakhtunkhwa, Pak Sarhad J Agri 34(2): 258-267.

2. Habeeb AAM, Gad AE, EL-Tarabany AA, Mustafa MM \& Atta MAA (2017). Using of Sugar Beet Pulp Byproduct in Farm Animals Feeding. Int J Scientific Res Sci Tech 3(3): 107-120.

3. Broughton NW, Dalton CC, Jones GC \& Williams EL (1995). Adding value to sugar beet pulp. Inter Sugar J 97(1): 5760.

4. Mustafa MM, Saleh MHM \& EL-Fouly HA (2009). Effect of olive by-product inclusion in lamb's diet on productive performance and some blood parameters. Egyptian J Nutr and Feeds 12(3): 253-262.
5. Mustafa MMM (2011). Effect of dried olive oil By-Product supplementation to Ration on the Performance of Local Ewes and Their Lambs. Isotope \& Rad Res 40(4): 507-518.

6. Emam RMS \& Abdel Wahed HM (2018). Effect of inclusion of sugar beet pulp in the diets on the performanceand egg quality of Gimmizah laying hens. Egyptian J. Nutrition and Feeds 21: 126.

7. El-Badawi AY, El-Badawy TM \& ElKady RI (2001). Inclusion of sugar beet pulp in ruminant diets; 1. Effect of untreated sugar beet pulp feeding level of feed utilization and weight gain of local growing sheep. Egyptian J Nut and Feeds 4(2): 101-111.

8. Mohsen MK, Ali MF \& Basiouni MS (1999). The effect of partial replacing concentrate mixture by dried sugar beet pulp on performance of Angora goats. Egyptian J Nut and Feeds 1: 309.

9. Nagy EM, Cota C, Cioica N, Gyorgy Z \& Deac T (2019). Researches on the higher valuation of sugarbeet pulp from sugar production to obtain premixes for animal feed. E3S Web of Conferences 112: 1-6.

10. Guzman P, Saldana B, Mandalawi HA, Perez-Bonilla A, Lazaro R \& Mateos GG (2015). Productive performance of brown-egg laying pullets from hatching to 5 weeks of age as affected by fiber inclusion, feed form, and energy concentration of the diet. Poult Sci 94: 249-261.

11. Sarikhan M, Shahryar HA, Gholizadeh B, Hosseinzadeh $\mathrm{MH}$, Beheshti B \& Mahmoodnejad A (2010). Effects of insoluble fiber on growth performance, carcass traits and ileum morphological parameters on broiler chick males. Inter J Agri and Biol 12: 531-536. 